Editor's Note: In each issue of Current Sports Medicine Reports we will run an interview with a prominent ACSM clinician member, to get his or her perspective on the current status of the field of sports medicine, where we have been, and where we should be going. This first issue features John Bergfeld, MD, FACSM. Dr. Bergfeld has had a distinguished career as an orthopedic surgeon at the Cleveland Clinic and as team physician for the National Football League's Cleveland Browns. He is a past ACSM president and has been a leader in advancing the role of the team physician.

\title{
ACSM Clinician Profile
}

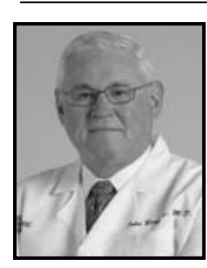

John Bergfeld, MD, FACSM, is currently the Director of Medical Affairs at The Cleveland Clinic Sports Health. A physician, surgeon, teacher, lecturer, and consultant, Dr. Bergfeld has previously served for many years as the team physician for the National Football League's Cleveland Browns and the National Basketball Association's Cleveland Cavaliers. He has been a member of the American College of Sports Medicine since 1968, served as President from 1984 to 1985, and was a member of the Board of Directors from 1980 to 1987. Dr. Bergfeld earned his BS at Bucknell University and his MD from Temple University. He has published nearly 100 articles in various medical journals.

You have been a real pioneer regarding team physician issues. How has the job of team physician evolved over the years? I think the best part is the advances that have been made to help team physicians diagnose and treat injuries more effectively. I also think that recognition of the value of sports medicine by high schools and universities has improved over the years. These days almost all medical schools and residency programs offer training for the team physicians; that wasn't the case several years ago. I think the development of primary care in sports medicine has improved significantly with the collaboration of the orthopedic surgeon, team physician, and primary care team physician working together.

You have been a member of ACSM since 1968; how has ACSM grown and changed over the years? Well, ACSM membership has definitely grown in numbers! In the past it seemed as though ACSM was somewhat dominated by exercise physiologists, but now there is a real intention to include clinical physician members. I think that the offerings for clinicians has improved at the Annual Meeting. The rotation of elected offices, held by basic/applied science and medical professionals, has helped as well. Also, in 1968 ACSM did not have any position stands; today these are an integral part of the organization's outreach.
What was it like to be a clinician in the 1960s and 1970s, compared with today? The patients are the same-it's still a patient and a doctor in an examination or training room; no one can take that away! Today we are more aware of the cost of medicine and how a patient pays for care. The paperwork involved with that aspect has definitely increased over the years. Another significant difference is how specialized practice has become. Orthopedics is a good example. Back in the 1960s and 1970s, you were simply an orthopedic surgeon, but today orthopedic surgeons are very specialized in distinct areas such as shoulder, spine, foot and ankle, or hand and wrist.

How has membership in ACSM influenced your career? It has given me a real appreciation for exercise science. Because of my ACSM membership, I've had the opportunity to interact with and learn from elite exercise scientists. ACSM also afforded me the opportunity to hold a leadership position and the experience of coordinating ACSM board meetings and influencing the direction of ACSM.

What is your best advice to other sports medicine clinicians? My best advice is to always keep the patient in mind no matter what. I know that you have to pay attention to the financial aspect of care, but don't let that distract you from caring for your patients. Beware of medical marketing, it's everywhere! Don't let marketing be the dominating force for determining how you treat your patients.

Where do you see ACSM heading in the future? ACSM is alive and well! I'd like to see even more emphasis put on meeting the physician's needs in the future. One way to do this would be to continue to increase the clinical programs at the Annual Meeting. ACSM needs to recruit and maintain the sports medicine clinician.

Would you like to share anything else with the readers of Current Sports Medicine Reports? I would like to stress that being a team physician is an honor and a privilege, not a right. It's important to remember that athletes and coaches are putting their trust in you, so you have a big responsibility to live up to. 